\title{
Genetic Variability and Proteome Profiling of a Radiation Induced Cellulase Mutant Mushroom Pleurotus florida
}

\author{
CHANDRAN SATHESH-PRABU and YOUNG-KEUN LEE*
}

Advanced Radiation Technology Institute, Korea Atomic Energy Research Institute, Jeongeup, Korea

Submitted 23 September 2013, revised 13 April 2015, accepted 11 February 2016

Abstract

We report the genetic similarity changes between a mutant mushroom (Pleurotus florida, designated as PfCM4) having increased cellulolytic activity developed through radiation mutagenesis and its wild type by amplified fragment length polymorphism (AFLP). On average, 23 AFLP fragments were amplified per primer combination, and a total of 286 polymorphic fragments ( $78.57 \%$ polymorphism) with maximal fragment length of 1365 base pairs (bp) were obtained. The genetic similarity between wild type and PfCM4 was found to be $22.30 \%$. In addition, mycelial and secreted protein profiling by 2D-PAGE showed at least three and five different protein spots in the range of $25 \mathrm{kD}$ to $100 \mathrm{kD}$, respectively, in PfCM4. It seems that the variation in genetic similarity and different expression of both mycelial and secreted proteins in PfCM4 in comparison to the wild type could likely be correlated with its increased cellulolytic activity effected by the irradiation.

Ke y word s: Pleurotus florida, 2D-PAGE, AFLP, genetic variability, mushroom

\section{Introduction}

Oyster mushrooms (Pleurotus spp.) are economically important in the world mushroom market and hold second place in the world's production of edible mushrooms, after the popular white button mushroom, Agaricus bisporus (Chang, 1999; Berne et al., 2008). In addition, the genus Pleurotus comprises about 40 species (Jose and Janardhanan, 2000). These mushrooms are known not only for their culinary and medicinal properties, but also for their potential applications in multifarious fields, including disposing of agro-lignocellulosic wastes, important industrial production, and environmental conservation (Sathesh-Prabu and Lee, 2012). Mutation breeding is a process by which mutant variants with desirable traits to be bred are developed, without altering the remaining genotype, by physical, chemical and biological mutagenic agents (SatheshPrabu and Lee, 2011). In a previous study, we developed a potent cellulase mutant of Pleurotus florida, designated as PfCM4, induced by gamma radiation at a dose of $\mathrm{LD}_{99}(0.51 \mathrm{kGy})$ (Sathesh-Prabu and Lee, 2012) that showed $17.24 \%$ more cellulolytic activity than wild type $(\mathrm{p}<0.05)$. Boominathan et al., (1990) observed that gamma-ray radiation can change the genetic diversity of filamentous fungi and induce positive mutants. The genetic similarity of mycelia and basidiospores was altered according to the dose of gamma radiation (Lee and Chang, 1999). Amplified fragment length polymorphism (AFLP) is a highly accurate fingerprinting method to detect polymorphisms among individuals, populations, and independently evolving lineages (Mueller and Wolfenbarger, 1999). Reproducibility, reliability, and specificity are the main advantages of the AFLP technique that has already been applied to establish genetic differences among Pleurotus sp. (Mueller and Wolfenbarger, 1999; Urbanelli et al., 2007; Pawik et al., 2012). Exposure to gamma radiation results in more extensive transcriptional changes (Fry et al., 2006) and might change the expression of proteins. Proteomic technologies are powerful tools for examining alterations in protein profiles (Dubey and Grover, 2001). The 2D-PAGE (Two-dimensional polyacrylamide gel electrophoresis) approach to protein profiling is an accessible, economical, and robust technique that possesses high resolving power and enables the detection of hundreds of proteins on a single gel plate (Issaq and Veenstra, 2008). In this vein, the present study was carried out to evaluate the effect of gamma radiation on the genetic similarity of the cellulase mutant P. florida (PfCM4) by using AFLP, and differentially expressed mycelial and secreted proteins were investigated by $2 \mathrm{D}$-PAGE.

\footnotetext{
* Corresponding author: Y.-K. Lee, Advanced Radiation Technology Institute, Korea Atomic Energy Research Institute, Jeongeup, Korea; e-mail: yklee@kaeri.re.kr
} 


\section{Experimental}

Materials and Methods

DNA extraction. DNA extractions were performed by the standard CTAB method with slight modifications. Fresh mycelia of wild type and PfCM4 (0.1 g) were collected from 7 -day old cultures grown in potato dextrose broth by centrifugation at $15000 \times \mathrm{g}$ for $10 \mathrm{~min}$ and frozen with liquid nitrogen. Frozen mycelia were ground with a sterile mortar and pestle and kept in a $1.5 \mathrm{ml} \mathrm{micro-tube}$. The preheated $\left(65^{\circ} \mathrm{C}\right.$ for $\left.30 \mathrm{~min}\right)$ $2 \mathrm{X} \mathrm{CTAB} \mathrm{extraction} \mathrm{buffer}(700 \mu \mathrm{l})$ was added to each of the micro-tubes and the mixture incubated at $65^{\circ} \mathrm{C}$ for $30 \mathrm{~min}, 700 \mu \mathrm{l}$ of Chloroform:Isoamyalcohol (24:1) was then added followed by centrifugation at $14000 \mathrm{rpm}$ for $30 \mathrm{~min}$ at $4^{\circ} \mathrm{C}$. Afterwards, the top aqueous upper phase was transferred to a $1.5 \mathrm{ml}$ micro-tube and two volumes of $95 \%$ alcohol were added and incubated on ice for $10 \mathrm{~min}$ followed by centrifugation at $15000 \times \mathrm{g}$ for 10 minutes at $4^{\circ} \mathrm{C}$. Subsequently, the collected pellet was washed with $70 \%$ alcohol, then air dried, and the DNA pellet was resuspended in $200 \mu \mathrm{l}$ of TE buffer. The purity and concentration of the extracted DNA were estimated by nanodrop spectroscopy (NanodropND1000), and the quality of the DNA was obtained by means of electrophoresis in 1\% agarose gels, followed by staining with ethidium bromide. A DNA stock solution was kept at $-20^{\circ} \mathrm{C}$ for further analyses.

Amplified fragment length polymorphism. The AFLP analysis was carried out as previously described by Vos et al., (1995) with some modifications and the instruction manual for the AFLP analysis system for microorganisms (Invitrogen, CA). The adapter, primer sequences and reaction buffers employed for AFLP were procured from Invitrogen and are listed in Table I.

DNA restriction and ligation of adapters. Aliquots of the extracted DNA (250 ng) were digested with $2.5 \mathrm{U}$ each of EcoRI and MseI in $5 \mu$ lof a $5 \mathrm{X}$ restriction buffer (50 mM Tris- $\mathrm{HCl}$ pH7.5, $50 \mathrm{mM} \mathrm{Mg-acetate,} 250 \mathrm{mM}$ $\mathrm{K}$-acetate) in a final volume of $25 \mu \mathrm{l}$ for $2 \mathrm{~h}$ at $37^{\circ} \mathrm{C}$. After incubation, the mixture was incubated at $70^{\circ} \mathrm{C}$ for $15 \mathrm{~min}$ to inactivate the restriction endonucleases. Twenty-four micro litres of an adapter ligation solution (EcoRI/MseI adapters, $0.4 \mathrm{mM}$ ATP, $10 \mathrm{mM}$ Tris- $\mathrm{HCl}$ $\mathrm{pH} 7.5,10 \mathrm{mM}$ Mg-acetate, $50 \mathrm{mM}$ K-acetate) and $1 \mathrm{U}$ of T4 DNA ligase (in $10 \mathrm{mM}$ Tris- $\mathrm{HCl} \mathrm{pH} 7.5,1 \mathrm{mM}$ DTT, $50 \mathrm{mM} \mathrm{KCl}, 50 \%$ glycerol) was added to $25 \mu \mathrm{l}$ of restricted DNA and incubated for $2 \mathrm{~h}$ at $20^{\circ} \mathrm{C}$. After ligation, the reaction mixture was diluted tenfold in a $1 \mathrm{X}$ TE buffer (10 mM Tris-HCl pH 8.0, 0.1 MM EDTA) and used as a template for amplification reactions.

Non-selective PCR amplification. Non-selective PCR was performed to generate a template DNA with AFLP primers, each having zero selective nucleotides.
Table I

Adapter, primer sequences and primer combinations used for AFLP analysis.

\begin{tabular}{|l|l|}
\hline EcoRI - adapter 1 & 5'-CTC GTA GAC TGC GTA CC-3' \\
EcoRI - adapter 2 & 5'-AAT TGG TAC GCA GTC TAC-3' \\
\hline MseI - adapter 1 & 5'-GAC GAT GAG TCC TGA G-3' \\
MseI - adapter 2 & 5'-TAC TCA GGA CTC AT-3' \\
\hline EcoRI primer (E) & 5'-GAC TGC GTA CCA ATT C-3' \\
\hline MseI primer (M) & 5'-GAT GAG TCC TGA GTA A-3' \\
\hline Selective primers & \\
EcoRI+2 (E+2) & \\
EcoRI+AC & 5'-GAC TGC GTA CCA ATT CAC-3' \\
EcoRI+AA & 5'-GAC TGC GTA CCA ATT CAA-3' \\
MseI+1 (M+1) & 5'-GAT GAG TCC TGA GTA AA-3' \\
MseI+A & 5'-GAT GAG TCC TGA GTA AC-3' \\
MseI+C & 5'-GAT GAG TCC TGA GTA AG-3' \\
MseI+G & 5'-GAT GAG TCC TGA GTA AT-3' \\
MseI+T & \\
\hline Primer combinations & Set II (E+1/M+1) \\
Set I (E+2/M+1) & E+A/M+A \\
E+AC/M+A & E+C/M+A \\
E+AC/M+C & E+G/M+A \\
E+AC/M+G & E+T/M+A \\
E+AC/M+T & E+C/M+C \\
E+AA/M+A & E+T/M+C \\
E+AA/M+C & E+G/M+T \\
E+AA/M+G & E+T/M+T \\
E+AA/M+T & \\
\hline
\end{tabular}

Amplification was performed on $5 \mu$ of ligated DNA in a total volume of $51 \mu \mathrm{l}$ containing EcoRI +0 and $\mathrm{MseI}+0$ primers, $5 \mu \mathrm{l}$ of a $10 \mathrm{X}$ PCR reaction buffer $(100 \mathrm{mM}$ Tris- $\mathrm{HCl} \mathrm{pH} 8.3,15 \mathrm{mM} \mathrm{MgCl} 2,500 \mathrm{mM} \mathrm{KCl})$, and $5 \mathrm{U}$ of Taq DNA polymerase (PKT, Korea). Amplifications were carried out on a thermal cycler (MJ Research Inc., Korea) with the following conditions: $20 \mathrm{X}\left(94^{\circ} \mathrm{C}\right.$ for $30 \mathrm{~s}, 56^{\circ} \mathrm{C}$ for $1 \mathrm{~min}$ and $72^{\circ} \mathrm{C}$ for $\left.1 \mathrm{~min}\right)$. After amplification, the samples were diluted to 1:50 with a TE buffer and used for the selective PCR amplification.

Selective PCR amplification. The non-selective amplified products were further amplified using EcoRI (E) and MseI (M) primers with two or one selective nucleotides. Two sets containing 16 primer combinations (Set I: $\mathrm{E}+2 / \mathrm{M}+1$; Set II: $\mathrm{E}+1 / \mathrm{M}+1$ ) were prepared (Table I). Selective amplification was performed on a thermal cycler (MJ Research Inc., Korea) with the following conditions as follows: one cycle of $94^{\circ} \mathrm{C}$ for $2 \mathrm{~min}, 65^{\circ} \mathrm{C}$ for $30 \mathrm{~s}$, and $72^{\circ} \mathrm{C}$ for $2 \mathrm{~min}$, followed by 13 cycles of amplification with an annealing temperature decrease by a $0.7^{\circ} \mathrm{C} /$ cycle starting with $94^{\circ} \mathrm{C}$ for $30 \mathrm{~s}, 65^{\circ} \mathrm{C}$ for $30 \mathrm{~s}$, and $72^{\circ} \mathrm{C}$ for $1 \mathrm{~min}$, and ended with 23 cycles of $94^{\circ} \mathrm{C}$ for $30 \mathrm{~s}, 56^{\circ} \mathrm{C}$ for $30 \mathrm{~s}$, and $72^{\circ} \mathrm{C}$ for $1 \mathrm{~min}$.

Analysis of AFLP polymorphism. The selective amplified PCR products were run in an automated electrophoretic separator (Labchip GX II, Caliper life sciences, MA). Bands were scored manually as binary 
data for the presence (1) or absence (0) of the fragments. Bands that could not be scored unambiguously and bands with low intensity value $(<0.01 \mathrm{ng})$ were excluded. The binary information was used to calculate Jaccard's pairwise similarity coefficients using an SPSS-20 package.

\section{Proteome profiling by 2 D-PAGE}

Cell lysis and precipitation of mycelial proteins. Extraction of mycelial proteins of the wild type and mutant was carried out according to Nandakumar et al., (2003) with modifications. The harvested mycelia biomass (500 mg wet weight) and an equal amount of acid washed glass beads ( $0.5 \mathrm{~mm}$, BioSpec, USA) were added to a $2 \mathrm{ml}$ screwcap tube containing $1 \mathrm{ml}$ of a cell lysis buffer $(20 \mathrm{mM}$ Tris- $\mathrm{HCl} \mathrm{pH} \mathrm{7.6,10} \mathrm{mM} \mathrm{NaCl,}$ $0.5 \mathrm{mM}$ deoxycholate and $0.5 \mathrm{mM}$ PMSF). The mixture was agitated in a Mini-BeadBeater (BioSpec, USA) at maximum speed for $8 \mathrm{~min}$ (repeated cycles of $30 \mathrm{~s}$ on followed by $30 \mathrm{~s}$ cooling on ice). The homogenate was centrifuged $\left(15000 \times \mathrm{g}\right.$ for $10 \mathrm{~min}$ at $\left.4^{\circ} \mathrm{C}\right)$, and the collected supernatant was treated with DNase/RNase ( $7 \mu \mathrm{l} / \mathrm{ml}$ of DNase/RNase/Mg mix). To precipitate the proteins, 2 volumes of $10 \%$ tricholoroacetic acid (TCA) in acetone and $0.07 \%$ 2-mercaptoethanol (2-ME) were added and precipitated overnight at $-20^{\circ} \mathrm{C}$. Subsequently, the precipitated proteins were separated by centrifugation $\left(15000 \times \mathrm{g}\right.$ for $20 \mathrm{~min}$ at $\left.4^{\circ} \mathrm{C}\right)$. The pellet was washed three times with cold-acetone containing $0.07 \%$ 2-ME to remove the TCA and dried under a speed vacuum. Thirty microlitres of $0.2 \mathrm{M} \mathrm{NaOH}$ was added to the TCA precipitated dry powder for $2 \mathrm{~min}$ after which a $1 \mathrm{ml}$ solubilization buffer $(9 \mathrm{M}$ urea, $4 \% \mathrm{w} / \mathrm{v}$ CHAPS, $1 \% \mathrm{w} / \mathrm{v}$ DTT and ampholytes 2\% v/v 3-10 nonlinear) was added (vortexed occasionally for 1-2 $\mathrm{min}$ ) followed by sonication on ice for $20 \mathrm{~min}$. Insoluble material was removed by centrifugation $\left(15000 \times \mathrm{g}\right.$ for $20 \mathrm{~min}$ at $\left.4^{\circ} \mathrm{C}\right)$, and the supernatant was collected and stored at $-20^{\circ} \mathrm{C}$ for further use. The protein concentration was determined according to the method of Bradford (1976) with reference to bovine serum albumin using Bio-Rad protein assay reagents (Bio-Rad Laboratories).

Precipitation of secreted proteins. Culture supernatants of the wild type and mutant were collected from 7 -day old cultures grown in a $1 \%$ CMC medium by centrifugation $\left(15000 \times \mathrm{g}\right.$ for $20 \mathrm{~min}$ at $\left.4^{\circ} \mathrm{C}\right)$. The supernatant was concentrated by freeze-drying according to Fragner et al., (2009). Subsequent precipitation and quantification of secreted proteins were carried out by the methods described above.

Protein separation by 2D-PAGE. Immobiline Dry Strips (IPG strip, Bio-Rad Laboratories, $17 \mathrm{~cm}, \mathrm{pH}$ 4-7 NL) were rehydrated using an immobiline dry strip re-swelling tray. The IPG strips were allowed to rehydrate with protein samples $(50 \mu \mathrm{g})$ in the rehydration buffer ( $8 \mathrm{M}$ urea, $2 \% \mathrm{w} / \mathrm{v}$ CHAPS, $2 \%$ v/v ampholytes 3-10 nonlinear, $0.002 \%$ bromophenol blue and $7 \mathrm{mg} \mathrm{DTT} / 2.5 \mathrm{ml}$ ) for $16 \mathrm{~h}$. The strip was overlaid with mineral oil to avoid evaporation. Subsequently, the first dimensional isoelectric focusing (IEF) of the rehydrated strips was performed in an IPGphor system (GE Healthcare) at $20^{\circ} \mathrm{C}$ in gradient mode. The IEF was performed under the following conditions: $500 \mathrm{~V}$ for $1 \mathrm{~h}, 1000 \mathrm{~V}$ for $1 \mathrm{~h}, 8000 \mathrm{~V}$ for $3 \mathrm{~h}$, and finally $8000 \mathrm{~V}$ until it reaches $21.2 \mathrm{kVh}$. The maximal current per strip was set to $50 \mu \mathrm{A}$. Prior to the second dimensional electrophoresis, the focused strips were equilibrated with equilibration buffer I ( $6 \mathrm{M}$ urea, $75 \mathrm{mM}$ Tris- $\mathrm{HCl}$ $\mathrm{pH} 8.8,30 \%$ glycerol, $2 \%$ SDS, $0.002 \%$ bromophenol blue and 1\% DTT) and equilibration buffer II (equilibration buffer I excluding DTT) for $10 \mathrm{~min}$ each in a shaker. Second-dimensional vertical SDS-PAGE was performed in a Protean II xi system (Bio-Rad Laboratories) with a Laemmli tris-glycine SDS electrophoresis buffer. Strips were overlaid with an agarose sealing solution containing bromophenol tracking dye. Electrophoresis was performed at $16 \mathrm{~mA} /$ gel for $30 \mathrm{~min}$ followed by $24 \mathrm{~mA} /$ gel for $5 \mathrm{~h}$ or until the tracking dye reached within $1 \mathrm{~cm}$ of the gel bottom.

Silver staining and imaging of the gel. After electrophoresis, the gels were stained with a silver stain as described previously (Shevchenko et al., 1996) with slight modifications. Briefly, gels were fixed in 50\% methanol and $10 \%$ acetic acid for $1 \mathrm{~h}$ and followed by washing twice with $50 \%$ ethanol for $20 \mathrm{~min}$ each. The gels were sensitized with a solution containing $0.2 \mathrm{~g} / \mathrm{l}$ $\mathrm{Na}_{2} \mathrm{~S}_{2} \mathrm{O}_{3} \cdot 5 \mathrm{H}_{2} \mathrm{O}$ for $90 \mathrm{~s}$ followed by three rinses with water for $20 \mathrm{~s}$ each. The gels were then agitated with impregnation solution containing $2 \mathrm{~g} / \mathrm{lgNO}_{3}$ and $750 \mu \mathrm{l}$ of $37 \% \mathrm{HCOH} / \mathrm{l}$ for $40 \mathrm{~min}$ followed by two rinses with water for $20 \mathrm{~s}$ each. The gels were then developed with a developer containing $60 \mathrm{~g} / \mathrm{l} \mathrm{Na}_{2} \mathrm{CO}_{3}$, $0.5 \mathrm{ml}$ of $37 \% \mathrm{HCOH} / \mathrm{l}$, and a $20 \mathrm{ml} / \mathrm{l}$ sensitizing solution with intensive shaking until the desired intensity of staining was achieved. The development was terminated by discarding the reagent, followed by washing the gel with 5\% acetic acid. The gels were dried using a GelAir drying system (Bio-Rad Laboratories) according to the manufacturer's instructions and subsequently scanned for further analysis.

\section{Results and Discussion}

To obtain better quality and productivity in edible mushrooms such as Pleurotus sp., mutations could be applied, resulting in the desired characteristics that could be economically beneficial (Flegg et al., 1985; Djajanegara and Harosoyo, 2009). In the present study, 
a potent cellulase mutant of P. florida (PfCM4) was employed to study the genetic variability effected by gamma irradiation using AFLP and to investigate the differentially expressed mycelial and secreted proteins by $2 \mathrm{D}-\mathrm{PAGE}$. In our previous study, a mutant (PfCM4) was induced by gamma radiation at a dose of $\mathrm{LD}_{99}$ (0.51 kGy) at the Advanced Radiation Technology Institute, Korea Atomic Energy Research Institute, Korea (Sathesh-Prabu and Lee, 2012). To summarize, among 16 mutants, Pf CM4 showed $17.24 \%$ more cellulolytic activity than the wild type $(\mathrm{p}<0.05)$. This characteristic (increased cellulolysis) was found to be stable at up to four generations of sub-culturing. It was observed that Pf CM4 can utilize all kinds of carbon sources tested for their mycelia growth. Starch, xylan, and glucose favourably supported the radial mycelia extension, and the opposite was recorded in sorbose and chitin as a carbon source. Yeast extract and $\mathrm{NH}_{4} \mathrm{NO}_{3}$ have been recorded as the best organic and inorganic nitrogen sources, respectively. Pf CM4 was found to grow significantly faster, even at high temperature $\left(30^{\circ} \mathrm{C}\right)$, than wild type $(\mathrm{p}<0.05)$, and the optimal $\mathrm{pH}$ was 5.5-6.5.

The AFLP, a PCR-based technique, provides a novel and very powerful DNA fingerprinting technique for DNAs of any origin and complexity (Vos et al., 1995). AFLP showed enough sensitivity to detect polymorphisms among the strains (Urbanelli et al., 2007) and it is suitable for the identification and differentiation of intraspecies level as well as for determining their genomic relationships (Majer et al., 1996; Pawik et al., 2012). In the present study, the restriction enzymes, ECoRI and MseI, along with two sets of primer combinations (Set I: E+2/M+1; Set II: E+1/M+1), 8 combinations each, were used to generate AFLP fingerprinting of the wild type and mutant, PfCM4. The consolidated
Table II

Polymorphism of wild type and mutant PfCM4 by AFLP.

\begin{tabular}{|l|c|c|c|c|}
\hline $\begin{array}{c}\text { Primer } \\
\text { combina- } \\
\text { tions }\end{array}$ & $\begin{array}{c}\text { Total } \\
\text { no. of } \\
\text { fragments }\end{array}$ & $\begin{array}{c}\text { No. of } \\
\text { polymorphic } \\
\text { fragments }\end{array}$ & $\begin{array}{c}\text { Maximal } \\
\text { fragment } \\
\text { length }\end{array}$ & $\begin{array}{c}\text { Polymor- } \\
\text { phism } \\
(\%)\end{array}$ \\
\hline E+AC/M+A & 5 & 4 & 590 & 80.00 \\
\hline E+AC/M+C & 35 & 31 & 1289 & 88.57 \\
\hline E+AC/M+G & 31 & 29 & 1261 & 93.55 \\
\hline E+AC/M+T & 11 & 10 & 1275 & 90.91 \\
\hline E+AA/M+A & 72 & 50 & 1322 & 69.44 \\
\hline E+AA/M+C & 43 & 37 & 1365 & 86.05 \\
\hline E+AA/M+G & 16 & 13 & 1361 & 81.25 \\
\hline E+AA/M+T & 8 & 7 & 665 & 87.50 \\
\hline E+A/M+A & 20 & 17 & 974 & 85.00 \\
\hline E+C/M+A & 29 & 20 & 943 & 68.97 \\
\hline E+G/M+A & 17 & 10 & 877 & 58.82 \\
\hline E+T/M+A & 21 & 14 & 962 & 66.67 \\
\hline E+C/M+C & 15 & 11 & 1072 & 73.33 \\
\hline E+T/M+C & 18 & 11 & 1166 & 61.11 \\
\hline E+G/M+T & 11 & 10 & 970 & 90.91 \\
\hline E+T/M+T & 16 & 12 & 1110 & 75.00 \\
\hline Sum & 368 & 286 & - & - \\
\hline Average & 23 & 17.88 & - & 78.57 \\
\hline
\end{tabular}

results are presented in Table II. All primer combinations gave successful AFLP amplification bands in both the wild type and mutant (Fig. 1). A total of 286 polymorphic fragments with a maximal fragment length of 1365 base pairs (bp) were scored. The primer combination of $\mathrm{E}+\mathrm{AA} / \mathrm{M}+\mathrm{A}$ amplified the highest number of fragments (72), while the lowest number of fragments (5) were observed with the combination of $\mathrm{E}+\mathrm{AC} / \mathrm{M}+\mathrm{A}$. A significant genomic similarity change was observed

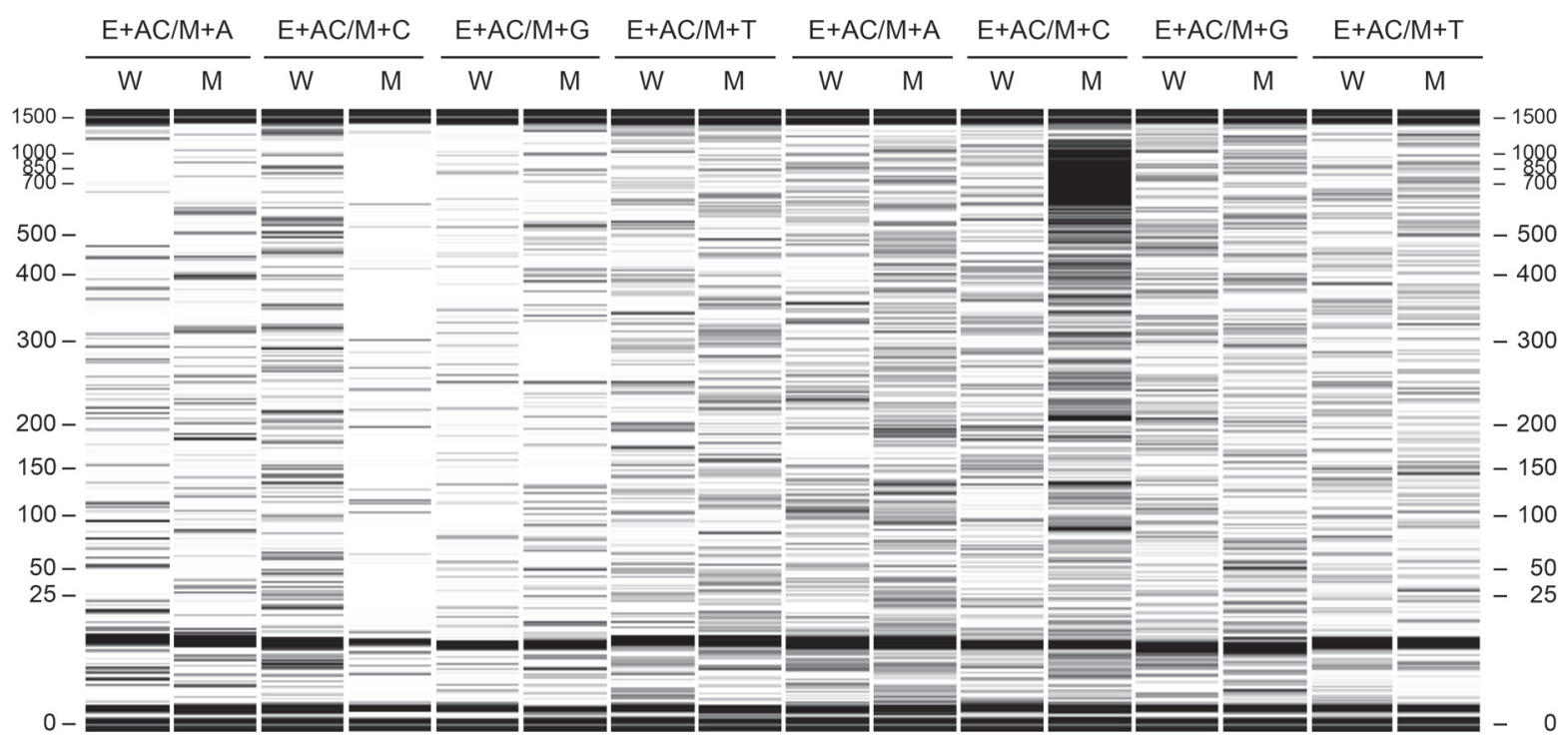

Fig. 1. AFLP fingerprinting of wild type (W) and mutant PfCM4 (M) was generated using the Set $\mathrm{I}(\mathrm{E}+2 / \mathrm{M}+1)$ primer combination. Bands that could not be scored unambiguously and bands with low intensity value $(<0.01 \mathrm{ng})$ were excluded. 
by an analysis of the AFLP profile. The genetic similarity between the wild and PfCM4 was found to be $22.30 \%$. In this study, as the genetic similarity was found to be low, the sequence of the internal transcribed spacer (ITS15.8S-ITS2) regions of the wild type and PfCM4 was analysed and found that both the wild type and PfCM4 belonged to $P$. florida (data not shown). The variable ITS regions have an advantage of the phylogenetic analysis and identification of the closely related fungal species (Kim et al., 1999; Park et al., 2001). Lee and Chang (1999) reported the genetic similarity percentage among the gamma irradiated mycelia in the range of $23-36 \%$ and $22-25 \%$ for the gamma irradiated basidiospores of Pleurotus ostreatus. Kwon et al. (2007) obtained 6-58\% of genetic dissimilarity between wild and irradiated mycelia of $P$. ostreatus and found that genetic similarity alteration is proportional to the radiation dose.

In this study, on average, 23 AFLP fragments were amplified per primer combination and a total of 286 polymorphic fragments $(78.57 \%$ polymorphism) were obtained. This efficiency is a little higher than the value obtained by an AFLP analysis in the sporeless mutants of Pleurotus eryngii (17.8 per primer combination) and in the congeneric species Pleurotus pulmonarius (18.0 per primer combination) (Okuda etal., 2009; 2012). Using only one restriction endonuclease (PstI) and four selective primers, the AFLP fingerprinting of 21 Pleurotus isolates was obtained with the genetic similarity between Pleurotus isolates ranging from 0-75\% (Pawlik et al., 2012). Urbanelli et al. (2007) generated a total of 94 AFLP polymorphic fragments of 90 specimens belonging to three taxa of P. eryngii complex with restriction enzymes, ECoRI and TaqI together with eight primer combinations. In the present study, AFLP primers with selective nucleotides determined the number of amplicons and corresponding percentage of polymorphism. Among all combinations, $\mathrm{E}+\mathrm{AC} / \mathrm{M}+\mathrm{G}$ gave the highest percentage of polymorphism (93.55\%). Set I primer combinations gave $81.90 \%$ of the average polymorphism, whereas Set II gave $71.43 \%$. It was observed that the Set I primer combinations showed $50.34 \%$ more generation of total fragments than Set II. Our results are partially consistent with Meng et al. (2003). Among the different combinations of AFLP primers used for AFLP profiling of $14 P$. ostreatus strains, $\mathrm{E}+3 / \mathrm{M}+3$ gave more amplified fragments than others such as $\mathrm{E}+2 / \mathrm{M}+1$ or $\mathrm{E}+2 / \mathrm{M}+3$ and found that the genetic distance ranged from 19-75\% between strains (Meng et al., 2003). In contrast, Pawlik et al. (2012) showed that the primers with three selective nucleotides amplified fewer restriction fragments compared to those with one and two selective nucleotides. Vos et al. (1995) demonstrated that the number of amplified fragments is affected by the selective nucleotides at the ends of the AFLP prim- ers. The change in genetic similarity evaluated by the AFLP suggested that the genetic similarity of $P$. florida could be altered by the gamma irradiation.

Mutation can alter the coding region or non coding region of a gene. Mutation altering the non coding region will cause different protein production or have no effect on mRNA maturation (Elliot and Langton, 1981). The estimated mycelial and secreted protein concentration in the wild type and mutant PfCM4 by the Bradford method was $289.07 \pm 29.60 ; 398.88 \pm 48.98$ and $307.69 \pm 21.53 ; 430.77 \pm 39.42 \mu \mathrm{g} / \mathrm{ml}$, respectively. It was found that mutant PfCM4 gave 37.90 and $40.00 \%$ increased mycelial and secreted protein concentrations, respectively, when compared to that of the wild type. In several studies, mutations that produce higher metabolites are mostly obtained by radiation mutagenesis (Slater, 2000). In this study, we used glass beads for a mechanical lysis of the cell to liberate cytoplasmic proteins because this approach has been more efficient than either chemical or enzymatic extraction methods (Nandakumar, 2002). To examine the expression of secreted and mycelial proteins in the wild type and PfCM4, we successfully employed the commonly utilized proteomics technique, 2D-PAGE. As mentioned by Kim et al. (2007), proteomic analysis is a powerful tool that can provide a systematic understanding of events at the molecular level.

In the present study, the proteins samples were first isoelectrofocused on a broad $\mathrm{pH}$ range IPGstrip, $\mathrm{pH} 3$ 10 , and it was observed that $95 \%$ of the protein spots were concentrated in acidic to a neutral $\mathrm{pH}$ range (data not shown). Hence, a narrow $\mathrm{pH}$ range IPGstrip, 4-7, was employed for the protein profiling. In the present study, four 2D PAGE gels were obtained corresponding to the mycelial and secreted proteins of the wild type and mutant PfCM4. Fig. 2 shows the quantitative comparison of the mycelial and secreted proteome profile prepared from wild type and mutant PfCM4 indicating the presence of protein spots with a wider range of molecular weights $(10 \mathrm{kD}$ to $150 \mathrm{kD})$ and acidic to neutral $\mathrm{pI}$ (4 to7). Protein spots that were determined to be reproducibly present in all three replicates performed for the mycelial and secreted proteins of wild type and mutant PfCM4 were taken for the study. About 145 and 182 protein spots were visualized from the mycelial and secreted proteins. However, the number of 2D-PAGE protein spots observed for both wild type and mutant PfCM4 seemed to be low when compared with those for other filamentous fungi (Nandakumar et al., 2003; Lakshman et al., 2008). It could be explained that a loss of proteins during solubilization of TCA precipitate is apparent in the preparation of samples for 2D-PAGE, and there is no single sample preparation protocol available to achieve a better sample preparation for electrophoresis thus avoiding protein modification 

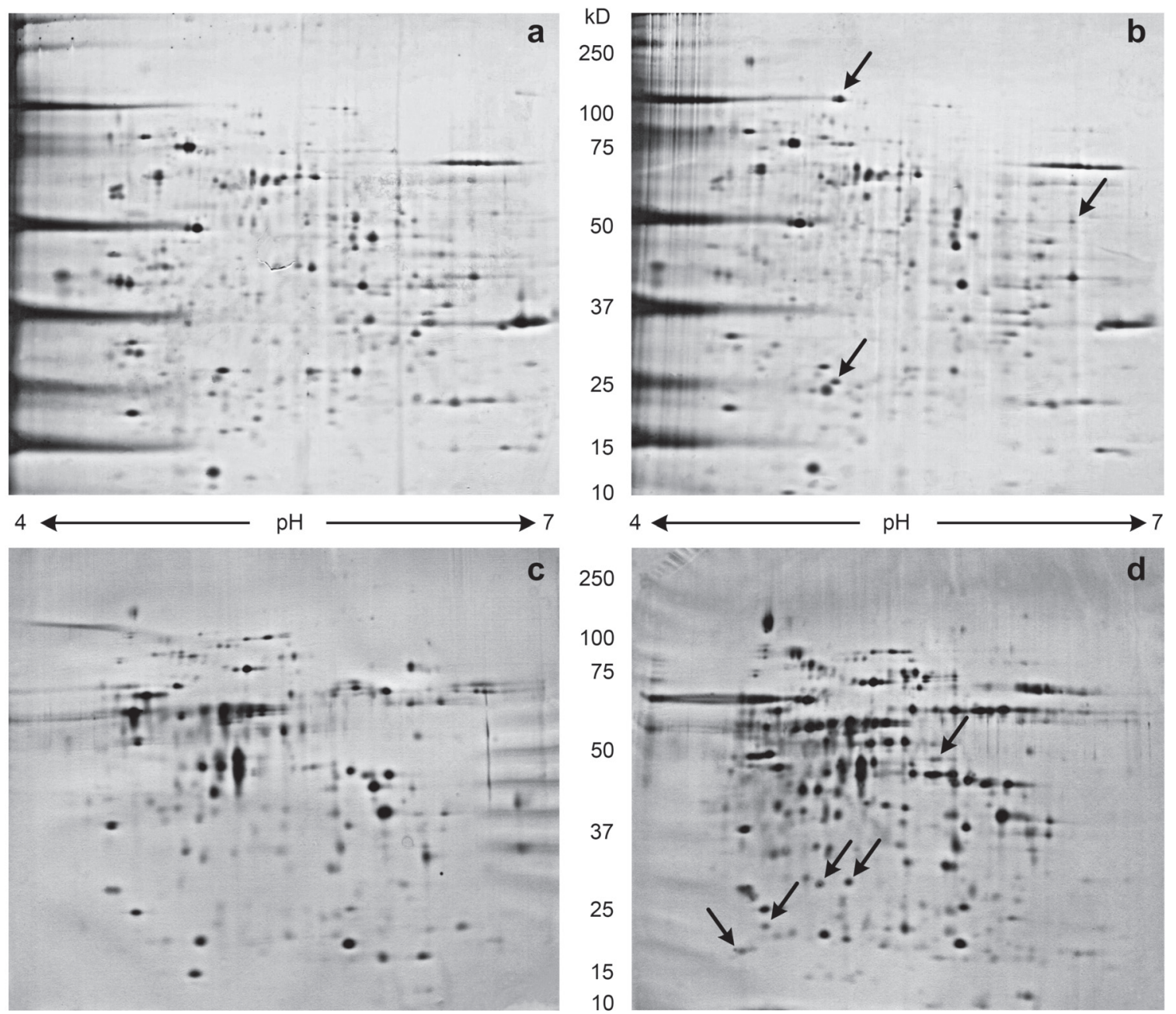

Fig. 2. 2D-PAGE profiles of mycelial proteins of wild type (a) and mutant PfCM4 (b); and secreted proteins of wild type (c) and mutant PfCM4 (d). Protein spots that were determined to be reproducibly present in all triplicates were taken into account. Arrows represent protein spots that were differently expressed than those of the wild type.

or degradation and/or a quantitative loss of proteins (Harder etal., 1999; Nandakumar et al., 2003). It was observed that there were three different protein spots $(100 \mathrm{kD} ; \mathrm{p} I 4.5-5.0,45-50 \mathrm{kD} ; \mathrm{p} I 6.0$ and $25 \mathrm{kD} ; \mathrm{pI} 4.5-5.0$ ) in the culture of PfCM4 (mycelial proteins) as compared to the wild type. HernandezMacedo et al. (2002) studied the intracellular filamentous fungal proteomics of Phanerochaete chrysosporium and Lentinula edodes using 2D-PAGE, and visualized 21 proteins related to iron uptake in these ligninolytic fungi. In the case of secreted proteins, a higher number of protein spots were visualized compared to mycelial proteins and it was found that five protein spots (50 kD; pI 5.5-6.0), 2 spots (25-37 kD; pI 5.0-5.5, $20 \mathrm{kD}$; pI 4.5-5.0 and $15 \mathrm{kD}$; pI 4.5-5.0) were differently expressed in the culture of PfCM4. Patel et al. (2013) obtained an extra band of protein in irradiated culture of Pleurotus sajor caju with two other more intense bands in comparison to the wild culture extract. In addition, in the present study, no streaking or tailing was observed, and no precipitation of proteins during gel running or staining was evident. Identi ication of differently expressed protein spots by MALDI-TOF MS and ESIMS/MS is now underway. It seems that the variation in genetic similarity and different expression of both mycelial and secreted proteins in PfCM4 in comparison to the wild type could likely be correlated with its increased cellulolytic activity effected by the irradiation.

\section{Conclusion}

The genetic similarity of the irradiated mycelia of P. florida could be changed by the gamma radiation and subsequently results in a different expression of mycelial and secreted proteins. The genetic similarity between the wild type and PfCM4 was found to be $22.30 \%$ as analysed by AFLP. Protein profiling of the mycelial and secreted proteins by 2D-PAGE showed at least three and five different protein spots in the range of $25 \mathrm{kD}$ to $100 \mathrm{kD}$ and $\mathrm{pI} 4$ to 7 , respectively, in PfCM4. Further studies will focus on the identification and 
characterization of differently expressed protein spots for a better understanding of the gamma-ray radiation effect on P. florida at the molecular level with the special reference to the increased cellulolytic activity.

\section{Literature}

Berne S., F. Pohleven, T. Turk and K. Sepcic. 2008. Induction of fruiting in oyster mushroom (Pleurotus ostreatus) by polymeric 3-alkylpyridinium salts. Mycol. Res. 112: 1085-1087.

Boominathan K., D.S. Balachandra, T.A. Randall and C.A. Reddy. 1990. Nitrogen-deregulated mutants of Phanerochaete chrysosporium-a lignin-degrading basidiomycete. Arch. Microbiol. 153: 260-265.

Bradford M.M. 1976. A rapid and sensitive method for the quantitation of microgram quantities of protein utilizing the principle of protein-dye binding. Anal. Biochem. 72: 248-254.

Chang S.T. 1999. World production of cultivated edible and medicinal mushrooms in 1997 with emphasis on Lentinus edodes (Berk) Sing in China. Int. J. Med. Mushrooms 1: 291-300.

Djajanegara I. and Harsoyo. 2009. Mutation study on white oyster mushroom (Pleurotus florida) using gamma $\left({ }^{60} \mathrm{Co}\right)$ irradiation.

J. Chem. Nat. Resour. Eng. 4: 12-21.

Dubey H. and A. Grover. 2001. Current initiatives in proteomics research: the plant perspective. Curr. Sci. 80: 262-269.

Elliot T.J. and F.A. Langton. 1981. Strain improvement in the cultivated mushroom Agaricus bisporus. Euphytica 30: 175-182.

Flegg P.B., D.M. Spencer and D.A. Wood. 1985. The biology and technology of the cultivated mushroom. John Wiley \& Sons, Toronto (eds.).

Fragner D., M. Zomorrodi, U. Kues and A. Majcherczyk. 2009 Optimized protocol for the 2-DE of extracellular proteins from higher basidiomycetes inhabiting lignocelluloses. Electrophoresis 30: 2431-2441

Fry R.C., M.S. Demott, J.P. Cosgrove, T.J. Begley, L.D. Samson and P.C. Dedon. 2006. The DNA-damage signature in Saccharomyces cerevisiae is associated with single-strand breaks in DNA. BMC Genomics 12: 313.

Issaq H.J. and T.D. Veenstra. 2008. Two-dimensional polyacrylamide gel electrophoresis (2D-PAGE): advances and perspectives. BioTechniques 44: 697-700.

Harder A., R. Wildgruber, A. Nawrocki, S.J. Fey, P.M. Larsen and A. Gorg. 1999. Comparison of yeast cell protein solubilization procedures for two-dimensional electrophoresis. Electrophoresis 20 : 826-829.

Hernandez-Macedo M.L., A. Ferraz, J. Rodriguez, L.M.M. Ottoboni and M.P. De-Mello. 2002. Iron-regulated proteins in Phanerochaete chrysosporium and Lentinula edodes: differential analysis by sodium dodecyl sulfate polyacrylamide gel electrophoresis and two-dimensional polyacrylamide gel electrophoresis profiles. Electrophoresis 23: 655-661.

Jose N. and K.K. Janardhanan. 2000. Antioxidant and antitumour activity of Pleurotus florida. Curr. Sci. 79:941-943.

Kim G.Y., M.G. Ha, T.H. Lee and J.D. Lee. 1999. Chemosystematic and molecular phylogeny of a new bioflocculant-producing Aspergillus strain isolated from Korean soil. J. Microbiol. Biotechnol. 9 870-872.

Kim Y., M.P. Nandakumar and M.R. Marten. 2007. Proteomics of filamentous fungi. Trends Biotechnol. 25: 395-400.
Kwon H.J., Y.J. Park, Y.B. Yoo, S.Y. Park and W.S. Kong. 2007. Genetic variability and phylogenetic relationship among proton beam irradiated strains of Pleurotus ostreatus. J. Microbiol. Biotechnol. 17: 1041-1044.

Lakshman D.K., S.S. Natarajan, S. Lakshman, W.M. Garrett and A.K. Dhar. 2008. Optimized protein extraction methods for proteomic analysis of Rhizoctonia solani. Mycologia 100: 867-875 Lee Y.K. and H.H. Chang. 1999. Radiation sensitivity of basidiospore and mycelium in Pleurotus ostreatus. J. Korean Nuclear Soc. 31: 287-293.

Majer D., R. Mithen, B.G. Lewis, P. Vos and R.P. Oliver. 1996. The use of AFLP fingerprinting for the detection of genetic variation in fungi. Mycol. Res. 100: 1107-1111.

Meng Y., C.S. Jiang and Y.Z. Zhang. 2003. AFLP fingerprinting map analysis of Pleurotus ostreatus. Yi Chuan Xue Bao. 30: 1140-1146. Mueller U.G. and L. Wolfenbarger. 1999. AFLP genotyping and fingerprinting. Trends Ecol. Evol. 14: 389-394.

Nandakumar M.P., J. Shen, B. Raman and M.R. Marten. 2003. Solubilization of Trichloroacetic acid (TCA) precipitated microbial proteins via $\mathrm{NaOH}$ for Two-dimensional electrophoresis. J. Proteome Res. 2: 89-93.

Okuda Y., S. Murakami. and T. Matsumoto. 2009. A genetic linkage map of Pleurotus pulmonarius based on AFLP markers, and localization of the gene region for the sporeless mutation. Genome 52: 438-446.

Okuda Y., J. Ueda, Y. Obatake, S. Murakami, Y. Fukumasa and T. Matsumoto. 2012. Construction of a genetic linkage map based on amplified fragment length polymorphism markers and development of sequence-tagged site markers for marker-assisted selection of the sporeless trait in the oyster mushroom (Pleurotus eryngii). Appl. Environ. Microbiol. 78: 1496-1504.

Park J.E., G.Y. Kim, H.S. Park, B.H. Nam, W.G. An, J.H. Cha, T.H. Lee and J.D. Lee. 2001. Phylogenetic analysis of caterpillar fungi by comparing ITS 1-5.8S-ITS 2 ribosomal DNA sequences. Mycobiol. 29: 121-131.

Patel Y., R. Naraian, K. Sunita, P. Abbasi and V.K. Singh. 2013. A new antibiotic resistant mutant of Pleurotus sajor-caju with improved expression of malate dehydrogenase enzyme. Int. J. Adv. Life Sci. 6: 36-43.

Pawlik A., G. Janusz, J. Koszerny, W. Malek. and J. Rogalski. 2012. Genetic diversity of the edible mushroom Pleurotus sp. by amplified fragment length polymorphism. Curr. Microbiol. 65: 438-445.

Sathesh-Prabu C. and Y.K. Lee. 2011. Mutation breeding of mushroom by radiation. J. Radiat. Ind. 5: 285-295.

Sathesh-Prabu C. and Y.K. Lee. 2012. Improvement of cellulolytic activity of Pleurotus florida through radiation mutagenesis. J. Radiat. Ind. 6: 181-188.

Shevchenko A., M. Wilm, O. Vorm. and M. Mann. 1996. Mass spectrometric sequencing of proteins from solver-stained polyacrylamide gels. Anal. Chem. 68: 850-858.

Slater R.J. 2000. Radioisotope technique. pp. 687-728. In: Wilson $\mathrm{K}$ and J. Walker (eds). Principle and Technique of Practical Biochemistry. $5^{\text {th }}$ ed. Cambridge University Press, Cambridge.

Urbanelli S., V.D. Rosa, F. Punelli, D. Porretta, M. Reverberi, A.A. Fabbri and C. Fanelli. 2007. DNA-fingerprinting (AFLP and RFLP) for genotypic identification in species of the Pleurotus eryngii complex. Appl. Gene. Mol. Biol. 74: 592-600.

Vos P., R. Hogers, M. Bleeker, M. Reijans, T. Lee, M. Hornes, A. Frijters, J. Pot, J. Peleman M. Kuiper and M. Zabeau. 1995. AFLP: a new technique for DNA fingerprinting. Nucl. Acids Res. 23: 4407-4414. 
